International Council for the Exploration of the Sea
ICES CM 2001/K:09

Theme Session on The Response of Cephalopod Populations and Fisheries to Changing Environment and Ecosystems

(Not to be cited without prior reference to the authors)

\title{
Early life stages of cephalopods in the Sargasso Sea: Distribution and diversity relative to hydrographic conditions
}

\author{
Rabea Diekmann* and Uwe Piatkowski \\ Institut für Meereskunde, Düsternbrooker Weg 20, 24105 Kiel, Germany \\ *E-mail address of corresponding author: rdiekmann@ifm.uni-kiel.de
}

\begin{abstract}
The distribution of early life stages of cephalopods was studied during a cruise of the German research vessel RV Poseidon to the Sargasso Sea in March 1993, covering an area south-east of Bermuda from $24^{\circ} \mathrm{N}$ to $31^{\circ} \mathrm{N}$ and $61^{\circ} \mathrm{W}$ to $65^{\circ} \mathrm{W}$. Hydrographic measurements were conducted by CTD and/ or XBT. The subtropical convergence zone was detected at a latitude of approximately $27^{\circ} 20^{\prime} \mathrm{N}$ and divided the Sargasso Sea into a northern and a southern area. Zooplankton sampling with a $6 \mathrm{~m}^{2}$ Isaac Kidd midwater trawl and Bongo nets yielded a total catch of 909 early life stages of cephalopods representing at least 14 families and 23 mainly oceanic species. Multivariate statistical analyses were performed in order to compare the species composition and abundance of cephalopods. Two different assemblages were clearly identified, north and south of the front. According to the position of the front an analysis of similarity (ANOSIM) was applied which confirmed the observed differences in species composition on a highly significant level. The Cranchiidae, mainly represented by the endemic species Leachia lemur, was the most abundant family especially in the northern part of the Sargasso Sea and was mainly responsible for the distinction between the cephalopod assemblages. In general, higher abundances of early life stages and a higher diversity was observed north of the subtropical convergence zone, which is assumed to form a faunal boundary.
\end{abstract}

Keywords: Cephalopoda, early life stages, distribution, abundance, Sargasso Sea, thermal front, STCZ 


\section{Introduction}

Central oceanic regions such as the Sargasso Sea have traditionally been thought to be low productive areas and have been compared with terrestrial deserts (Ryther 1963). Recent studies have shown that this assumption is partially wrong. In historical data sets the primary production in the oligotrophic central gyres has been underestimated by a factor of 2-4 (Goericke and Welschmeyer 1998), though productivity and biomass being still relatively low. A contrasting view is that the Sargasso Sea is characterised by a dynamic phytoplankton community with low biomass but high growth rates, that are balanced by high rates of grazing (Jackson 1980; Goldman 1993). Compared to slope and shelf waters, however, the Sargasso Sea shows consistently lower biomass concentrations in zooplankton (Deevey 1971; Deevey and Brooks 1977; Ortner et al. 1978; Wiebe et al. 1985; Ashjian et al. 1994). The distribution is less patchy and the average mean depth of the biomass concentration is similar during both day and night (Ashjian et al. 1994). The Sargasso Sea, however, is not a homogeneous water mass and the large-scale spatial distribution of zooplankton is not even at all. Distinct north-south differences are caused by a complex hydrography.

The Sargasso Sea lies within the North Atlantic Subtropical Convergence Zone (STCZ), a transition zone between the prevailing westerlies and the easterly trades (Voorhis 1969; Halliwell 1994). From fall to spring the slope of the mean seasonal thermocline is enhanced. The latitudinal surface temperature gradient forms an extensive large-scale thermal front, which is meandering in east-west direction (Voorhis 1969). The thermal gradient is an especially prominent feature during winter and spring and is only marginally detectable during summer (Halliwell et al. 1991), but there is also some evidence that the front may be present throughout the year (Backus et al. 1969; Colton et al. 1975). It separates the central part of the Sargasso Sea into a cooler, more productive northern part and a warmer, less productive southern part. The enhanced primary production north of the front, which may be up to 10 times higher than in the south, may be due to a deeper winter mixing compared with a stronger stratification of the water column south of it (Ryther and Menzel 1960). In correspondence with the differences in productivity a general decline in abundance and differences in species composition has been observed in north-south direction for e.g. epipelagic copepods (Colton et al. 1975) and mesopelagic fishes (Backus et al.1969).

Cephalopods have been frequently investigated in the western North Atlantic, but hardly any work has been performed in the Sargasso Sea. Expeditions in the beginning of the last century investigated the cephalopod fauna around Bermuda (e.g. Berry 1912; Pfeffer 1912; Peile 1926), but the number of hauls and the catchability of their nets were limited. The first intensive study was made by Voss (1960) who described the cephalopod fauna around the Bermuda islands. Catches with different net types yielded 21 cephalopod species of which at that time only three were previously reported from that area; however, detailed distribution patterns were not analysed. Since then the cephalopod fauna of the oceanic parts of the western North Atlantic have not been further studied. Investigations rather concentrated on the Florida Current (Cairns 1976; Lea 1984) and the Gulf Stream system (Dawe and Stephen 1988).

In this paper the cephalopod fauna of the Sargasso Sea is examined for the first time. In order to reduce avoidance effects and to ensure a nearly quantitative sampling (Piatkowski 1998) early life stages of cephalopods have been considered. The sampling was conducted with two different standard zooplankton nets (IKMT6, Bongo), essentially in north-south directions and, thus, crossing the STCZ. Distribution patterns of oceanic cephalopods are described and species assemblages are identified. Observed spatial differences in species composition are discussed with regard to hydrographic features of the region. 


\section{Materials and Methods}

\section{Sampling}

Data were collected in the Sargasso Sea during RV Poseidon cruise 200/1 in March 1993 which had been initiated to detect spawning grounds of the European eel Anguilla anguilla (Schnack et al. 1994). Stations were located south-east of Bermuda covering an area from $24^{\circ} \mathrm{N}$ to $31^{\circ} \mathrm{N}$ and $61^{\circ} \mathrm{W}$ to $65^{\circ} \mathrm{W}$ (Figure 1). Early life stages of cephalopods were sampled using a Bongo net $(500 \mu \mathrm{m}$ mesh size, 27 hauls), essentially on a north-south transect at $62^{\circ} \mathrm{W}$, and an Isaac Kidd midwater trawl (IKMT6, 300 $\mathrm{mm}$ mesh size, 9 hauls). The Bongo net was towed for approximately $90 \mathrm{~min}$ in downward oblique hauls between $100 \mathrm{~m}$ depth and the surface. The IKMT6 was applied in different depth from $300 \mathrm{~m}$ to $80 \mathrm{~m}$; towing time was approximately $60 \mathrm{~min}$. Ship speed during sampling was kept at $3 \mathrm{kn}$. Filtered water volumes were estimated using calibrated flowmeters, which were mounted in the centre of the net openings. All samples were initially preserved in $4 \%$ formalin, buffered with borax. Cephalopods were sorted and identified to the lowest taxonomic level possible. Cephalopod densities $\left(\mathrm{N} / 1000 \mathrm{~m}^{3}\right)$ were then estimated and used in the initial species-station table for the spatial analysis of cephalopod community structure.

Hydrographic data were collected using expendable bathythermographs (XBTs, 10 stations) and CTD casts (ME OTS 1500; 38 stations). XBTs were only deployed on the northern part of the $65^{\circ} \mathrm{W}$ transect (not illustrated in Figure 1). The CTD was launched on all other stations, always in advance to the zooplankton tows.

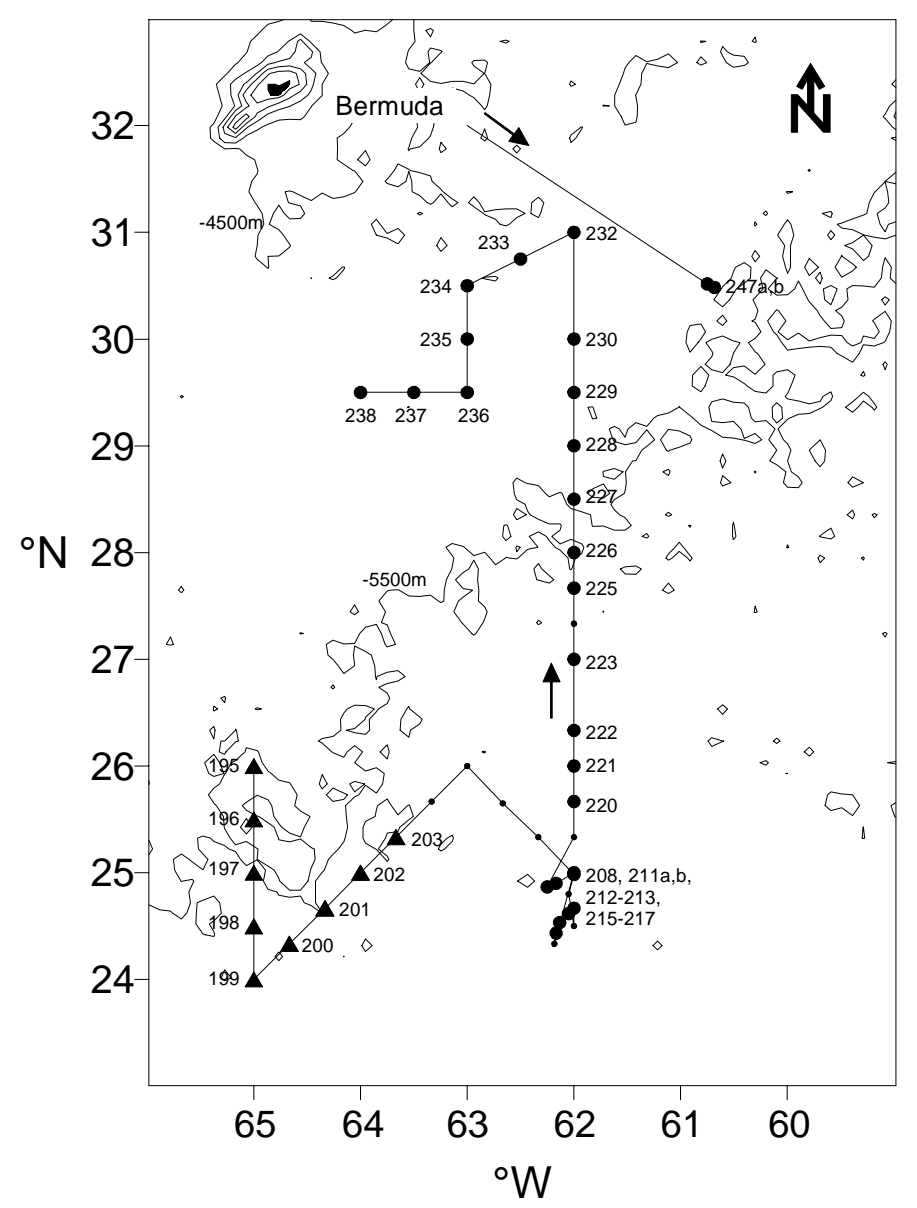

Fig.1. RV Poseidon cruise 200/1, March 1993. Sampling area in the Sargasso Sea. Bold points represent Bongo hauls, triangles IKMT6 hauls. CTD was applied on all marked stations. 


\section{Data analysis}

Multivariate statistical analyses were performed to examine differences in species composition and abundances of early life stages of cephalopods. IKMT6 hauls were not included in these analyses since only a few hauls in the southern Sargasso Sea were performed. Prior to the analysis the densities of cephalopod species $\left(\mathrm{N} / 1000 \mathrm{~m}^{3}\right)$ of each Bongo station were fourth-root transformed. The transformation reduced the weighting of dominant species and increased the importance of rare ones (Field et al. 1982). The similarity between stations was calculated by means of the Bray-Curtis measure (Bray and Curtis 1957; Field et al. 1982). Samples were classified by hierarchical agglomerative cluster analysis using the group average linking method and ordinated using non-metric multidimensional scaling techniques (MDS).

According to the prevailing hydrographic regimes the Sargasso Sea was separated into a northern and a southern region divided by the $27^{\circ} 20^{\prime} \mathrm{N}$ latitude. The cephalopod catches in these two regions were compared using different subroutines of the Primer-E. (5) computer program (Clarke and Warwick 2001). Analysis of similarities (ANOSIM; Clarke and Warwick 1994) was employed to test for differences in species composition between the two areas. In case of significant results in the ANOSIM the similarity percentage routine (SIMPER; Clarke and Warwick 1994) was applied to examine which cephalopod species were most responsible for contrasts in the community analysis. In addition various univariate indices, the Magalef index D, a measure of the species richness, the diversity index H' (Shannon-Wiener index) and Pielou's evenness index (J), were calculated for the samples north and south of the thermal front.

\section{Results}

\section{Oceanographic conditions}

Oceanographic data were measured on two transects in a north-south direction from $24^{\circ} \mathrm{N}$ to $31^{\circ} \mathrm{N}$ at a longitude of $65^{\circ} \mathrm{W}$ and $62^{\circ} \mathrm{W}$, respectively. On both sections a sharp nearsurface temperature gradient was detected, which demonstrated the location of the thermal front. South of the front the water was stratified whereas northward the surface layer was mixed. In Figure 2 the temperature profile at $62^{\circ} \mathrm{W}$, the transect of intensive sampling, is illustrated. The temperature gradient was encountered at approximately $27^{\circ} 20^{\prime} \mathrm{N}$. South of this front the $21^{\circ} \mathrm{C}$ isotherm was measured below $100 \mathrm{~m}$ water depth. To the north this isotherm reached the surface at approximately $29^{\circ} 30^{\prime} \mathrm{N}$. The northern area was characterised by a mixed layer of approximately $50-100 \mathrm{~m}$ depth. At $65^{\circ} \mathrm{W}$ the stratification in the southern area was slightly intensified and the most pronounced temperature gradient was again found at approximately $27^{\circ} 20^{\prime} \mathrm{N}$. 


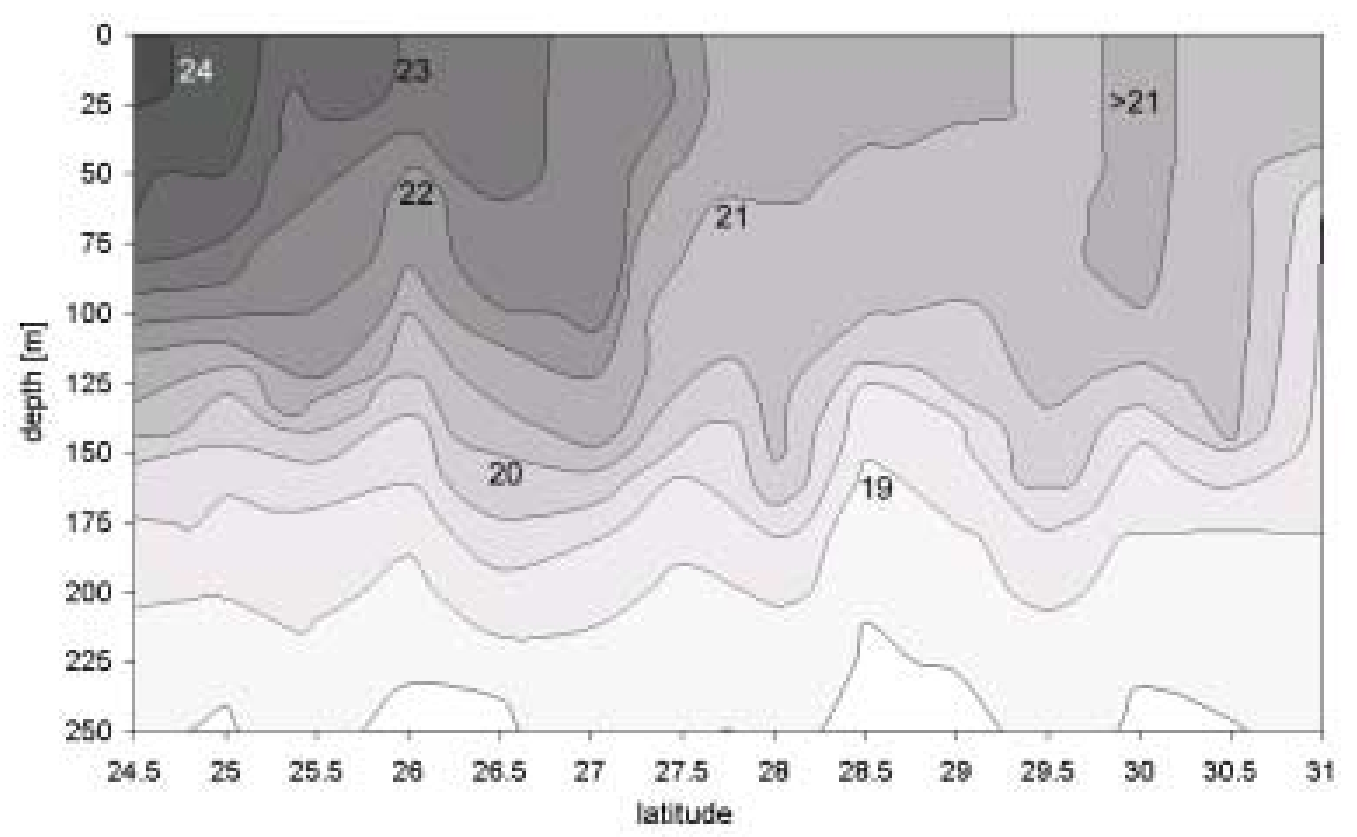

Fig.2. RV Poseidon cruise 200/1, March 1993. North-south temperature section at $62^{\circ} \mathrm{W}$ from $250 \mathrm{~m}$ depth to the surface.

\section{Cephalopod families and major species}

A total of 909 early life stages of cephalopods were caught in 11 IKMT6 and 27 Bongo hauls. 13 families and 20 species were identified (Tab. 1). Since many specimens could only be assigned to higher taxa the number of families and species must be considered as minimal. All specimens belonged to the Oegopsida and the incirrate Octopoda. In the Bongo hauls the Cranchiidae were dominating (38.2\%), mainly represented by the endemic species Leachia lemur. The Enoploteuthidae and the Onychoteuthidae were moderately abundant with 18.2 and $9.0 \%$, respectively. Most abundant species concerning the calculated densities were Leachia lemur $\left(0.72 \mathrm{~N} / 1000 \mathrm{~m}^{3}\right)$, followed by Abraliopsis pfefferi $\left(0.38 \mathrm{~N} / 1000 \mathrm{~m}^{3}\right)$, Onychoteuthis banksii $\left(0.26 \mathrm{~N} / 1000 \mathrm{~m}^{3}\right)$, Megalocranchia sp. $\left(0.22 \mathrm{~N} / 1000 \mathrm{~m}^{3}\right)$ and Selenoteuthis scintillans $\left(0.21 \mathrm{~N} / 1000 \mathrm{~m}^{3}\right)$.

Specimens sampled with the IKMT6 were generally larger compared to specimens from the Bongo catches. With the exception of Thysanoteuthis rhombus, which was only found in the IKMT6 samples, the same species were identified in the collections of both net types. However, the relative composition was different. Highest abundances in the IKMT6 samples were observed for the Enoploteuthidae and Onychoteuthidae, which each comprised $21.6 \%$ of the total catch. Rhynchoteuthion stages of Ommastrephidae accounted for $15.7 \%$. Cranchiidae were less abundant $(9.9 \%)$ and were dominated by Helicocranchia sp, mainly identifiable as $H$. papillata. Species densities were not calculated because of inaccurate flowmeter readings.

Differences in the total abundance of early life stages in day- or nighttime samples were not detected. Therefore, diel effects on the catchability of the two nets were not taken into further consideration. 
Tab. 1. Early life stages of cephalopods collected during the RV Poseidon cruise 200/1, March 1993. Numbers for higher taxa only include specimens that could not be further identified, $\mathrm{N}_{\text {abs: }}$ : total catch in numbers; rel. $\mathrm{N}$ [\%]: percentage of total catch according to gear type; mean species density: $\mathrm{N} / 1000 \mathrm{~m}^{3}$ (only Bongo net).

\begin{tabular}{|c|c|c|c|c|c|c|}
\hline \multirow[t]{2}{*}{ Order, Family } & \multirow[t]{2}{*}{ Species } & \multicolumn{3}{|c|}{ Bongo net } & \multicolumn{2}{|c|}{ IKMT 6} \\
\hline & & $\mathrm{N}_{\mathrm{abs}}$ & rel. N [\%] & $\mathrm{N} / 1000 \mathrm{~m}^{3}$ & $\mathrm{~N}_{\mathrm{abs}}$. & rel. $\mathrm{N}[\%]$ \\
\hline \multicolumn{7}{|l|}{ Order Teuthida } \\
\hline Family Ancistrocheiridae & Ancistrocheirus lesueurii & 4 & 0.75 & 0.02 & 5 & 1.33 \\
\hline Family Brachioteuthidae & Brachioteuthis sp. & 8 & 1.50 & 0.05 & 2 & 0.53 \\
\hline Family Chiroteuthidae & Chiroteuthis sp. & 8 & 1.50 & 0.05 & 3 & 0.80 \\
\hline Family Chtenopterygidae & Chtenopteryx sicula & 3 & 0.56 & 0.02 & 5 & 1.33 \\
\hline Family Cranchiidae & Cranchiidae indet. & 3 & 0.56 & 0.02 & & \\
\hline Cranchiinae & Leachia lemur & 126 & 23.60 & 0.72 & 6 & 1.60 \\
\hline \multirow[t]{5}{*}{ Taoninae } & Taoninae indet. & & & & 5 & 1.33 \\
\hline & Helicocranchia papillata & 24 & 4.49 & 0.06 & 15 & 4.00 \\
\hline & Helicocranchia sp. & 10 & 1.87 & 0.14 & 2 & 0.53 \\
\hline & Taonius pavo & 3 & 0.56 & 0.02 & 1 & 0.27 \\
\hline & Megalocranchia sp. & 38 & 7.12 & 0.22 & 8 & 2.13 \\
\hline \multirow[t]{3}{*}{ Family Enoploteuthidae } & Enoploteuthidae indet. & 27 & 5.06 & 0.15 & 51 & 13.60 \\
\hline & Enoploteuthis leptura leptura & 3 & 0.56 & 0.02 & & \\
\hline & Abraliopsis pfefferi & 67 & 12.55 & 0.38 & 30 & 8.00 \\
\hline Family Lycoteuthidae & Selenoteuthis scintillans & 36 & 6.74 & 0.21 & 19 & 5.07 \\
\hline Family Ommastrephidae & Ommastrephidae indet. & 13 & 2.43 & 0.07 & 25 & 6.67 \\
\hline \multirow[t]{2}{*}{ Ommastrephinae } & Ommastrephes bartramii & 7 & 1.31 & 0.04 & 16 & 4.27 \\
\hline & Hyaloteuthis pelagica & 6 & 1.12 & 0.03 & 18 & 4.80 \\
\hline \multirow[t]{2}{*}{ Family Onychoteuthidae } & Onychoteuthis banksii & 45 & 8.43 & 0.26 & 70 & 18.67 \\
\hline & Onykia cariiboea & 3 & 0.56 & 0.02 & 11 & 2.93 \\
\hline \multirow[t]{3}{*}{ Family Pyroteuthidae } & Pyroteuthidae indet. & 4 & 0.75 & 0.02 & 7 & 1.87 \\
\hline & Pyroteuthis margaritifera & 29 & 5.43 & 0.17 & 18 & 4.80 \\
\hline & Pterygioteuthis giardi giardi & 8 & 1.50 & 0.05 & 1 & 0.27 \\
\hline Family Thysanoteuthidae & Thysanoteuthis rhombus & & & & 2 & 0.53 \\
\hline \multicolumn{7}{|l|}{ Order Octopoda } \\
\hline Family Argonautidae & Argonauta argo & 6 & 1.12 & 0.03 & & \\
\hline Family Tremoctopodidae & Tremoctopus violaceus violaceus & 3 & 0.56 & 0.02 & 3 & 0.80 \\
\hline Sum & & 534 & & & 375 & \\
\hline
\end{tabular}

\section{Distribution of cephalopods in relation to the thermal front}

The investigation of early life stages of cephalopods in the Bongo hauls revealed marked north-south differences in abundance. North of the thermal front at $27^{\circ} 20^{\prime} \mathrm{N}$ densities of cephalopods were increasing from an average of $1.70 \mathrm{~N} / 1000 \mathrm{~m}^{3}$ in the southern part to $4.03 \mathrm{~N} / 1000 \mathrm{~m}^{3}$ in the north (Figure 3). Highest abundances were encountered north of $29^{\circ} \mathrm{N}$ with a maximum of $8.92 \mathrm{~N} / 1000 \mathrm{~m}^{3}$. 


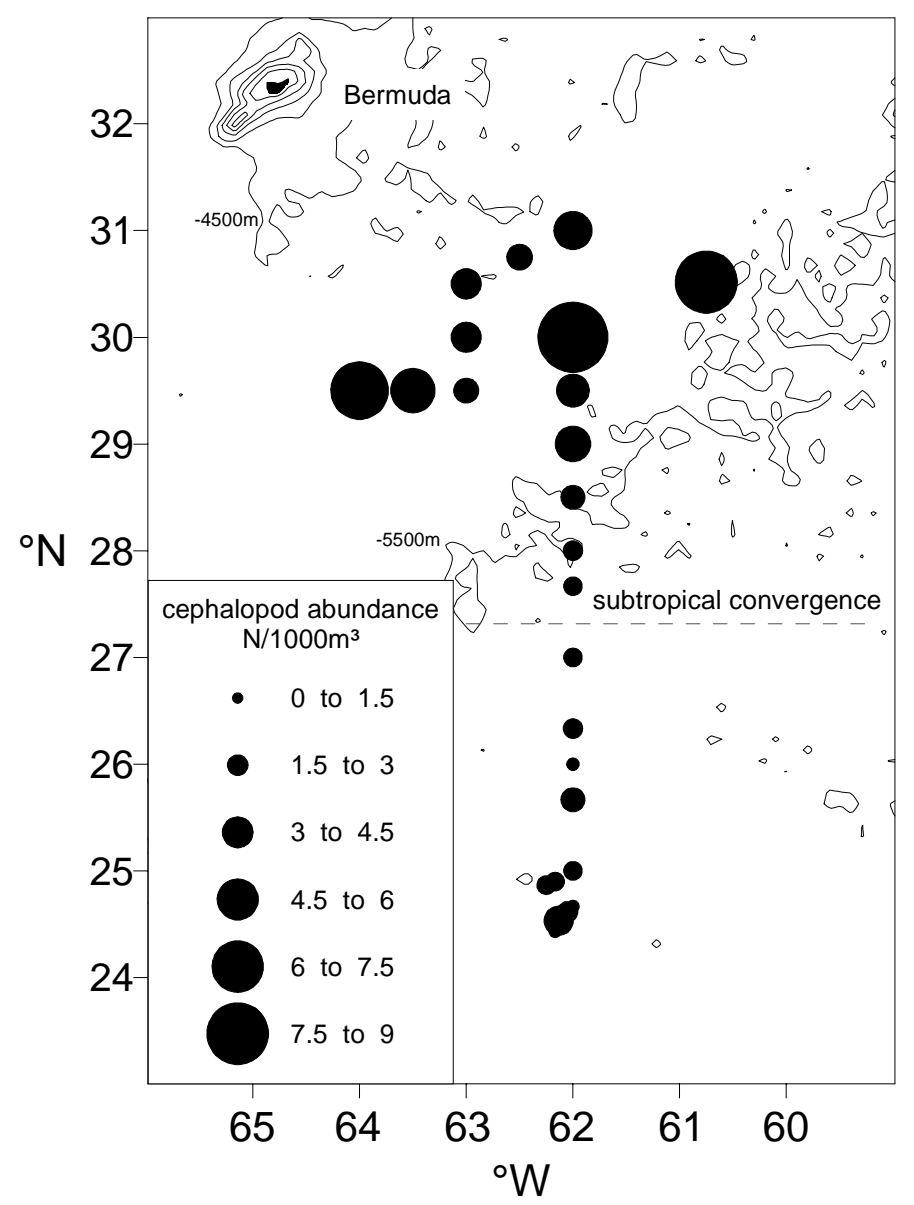

Fig. 3. RV Poseidon cruise 200/1, March 1993. Densities of cephalopod early life stages at each Bongo station $\left(\mathrm{N} / 1000 \mathrm{~m}^{3}\right)$. The horizontal line indicates the position of the thermal front at $62^{\circ} \mathrm{W}$.

Classification of the cephalopod densities in the Bongo hauls separated the 27 samples at an arbitrary level of $65 \%$ dissimilarity into two large (I and II) and one small cluster (III) (Figure 4). The first (I) and the third (III) cluster included all samples south of the subtropical convergence and three further stations north of it. The second cluster (II) comprised exclusively samples taken in the northern area of the Sargasso Sea. Ordination (non-metric multi-dimensional scaling, MDS) of the same data confirmed this finding (Figure 5): All samples from the northern Sargasso Sea were grouped to the right of a line drawn in a nearly vertical direction, whereas samples from the southern area were positioned to the left of this line. The sample from station 221 , which formed a single cluster (III) in the classification, was slightly separated from the other samples in the MDS plot (Figure 5). 


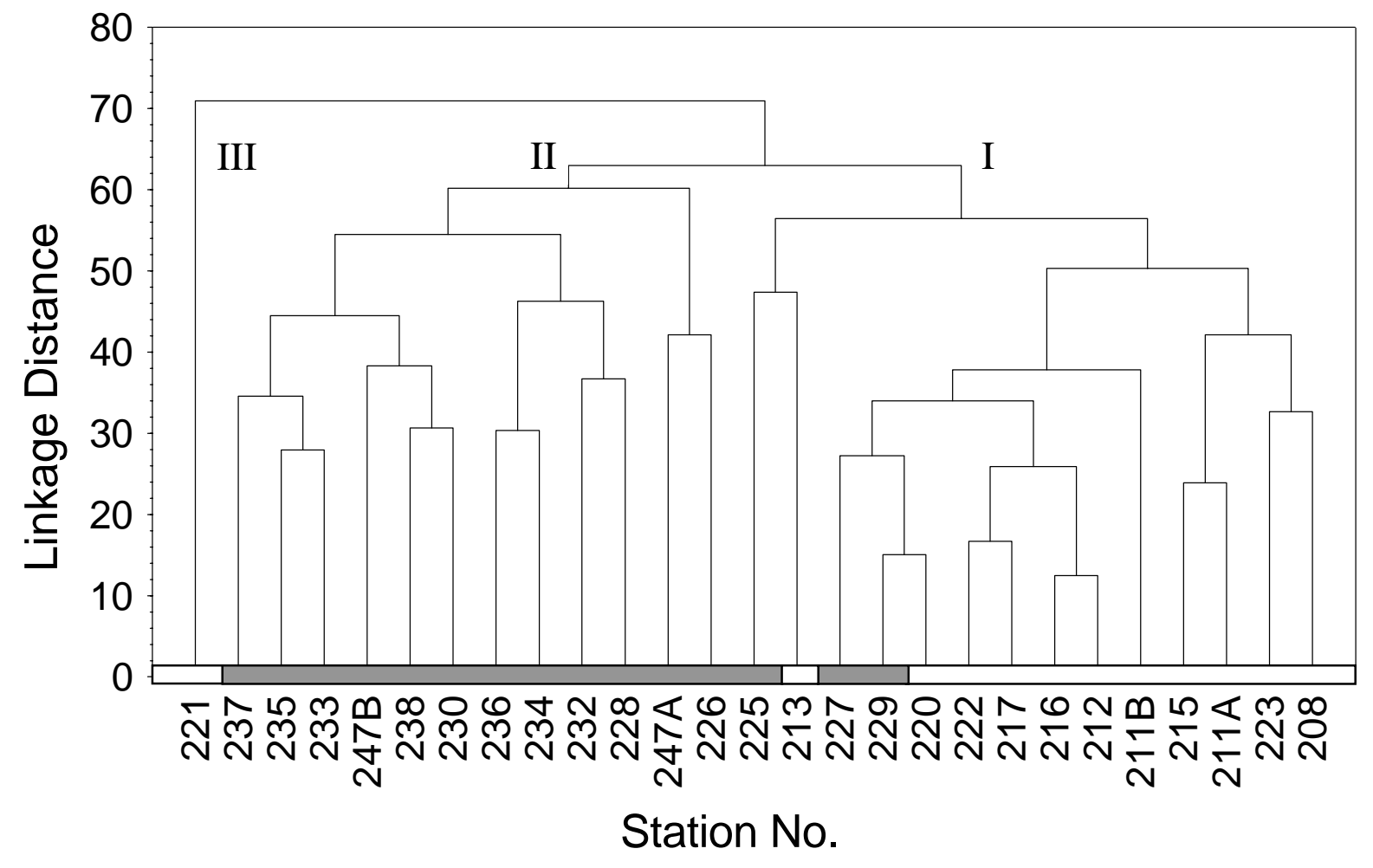

Fig. 4. Classification of the 27 Bongo stations according to cephalopod assemblages. Shaded bars indicate samples north of the thermal front.

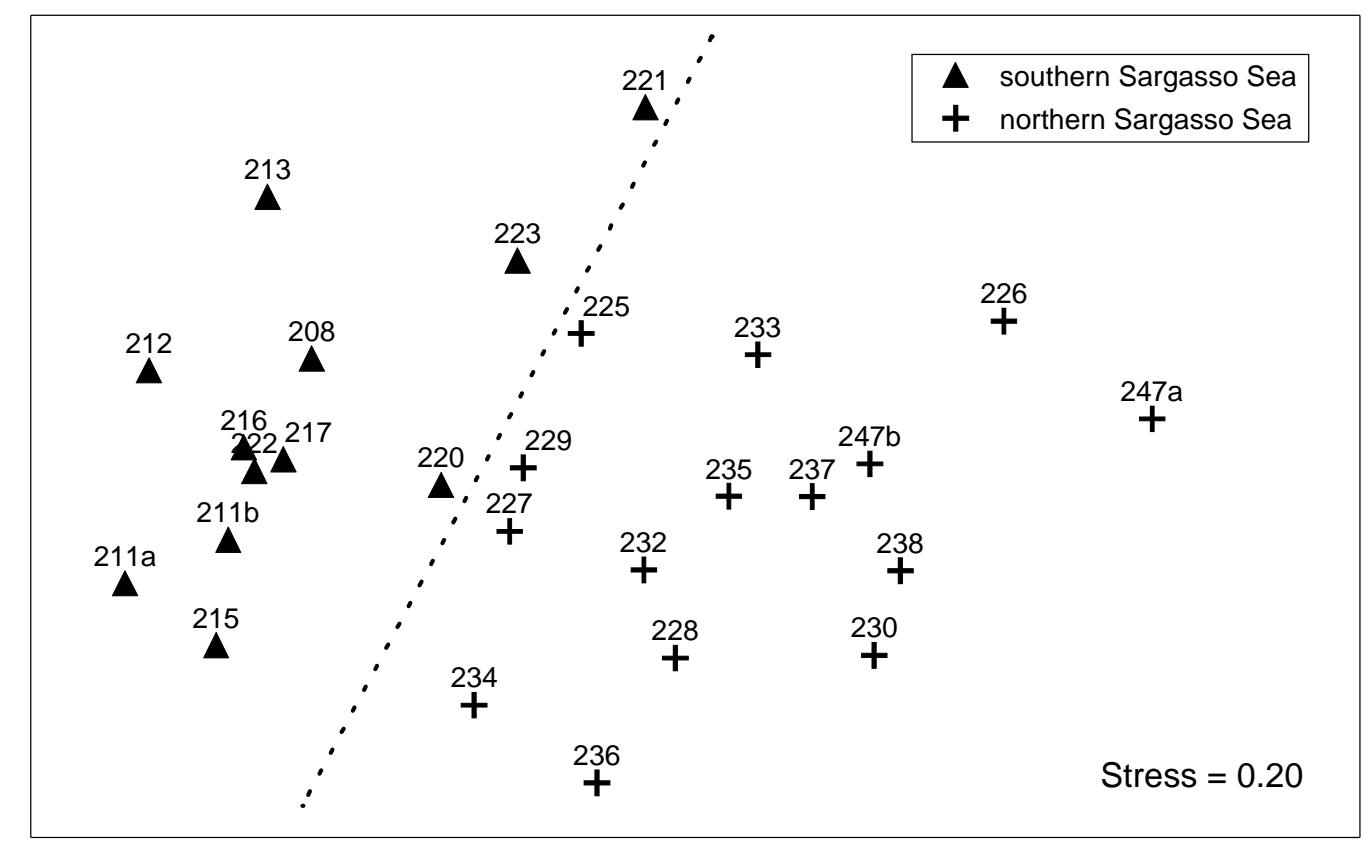

Fig. 5. Ordination of the 27 Bongo stations according to cephalopod assemblages. The line separates samples north of the thermal front from samples south of it. Stress $=0.20$.

In order to test the a priori hypotheses, that there are differences in the species composition between the northern and the southern part of the Sargasso Sea, an ANOSIM was performed. It showed, that the species compositions of both areas, separated by the 
STCZ, did significantly differ (global $R=0.481 ; p<0.001$ ) and, thus, supported the results from the classification and ordination. The following exploratory analysis (SIMPER) indicated which species contributed most to the differences between the samples from the northern and the southern stations (Table 2). The Cranchiidae dominated in the north. The family was mainly represented by Leachia lemur, Megalocranchia sp. and Helicocranchia sp., mostly identifiable as Helicocranchia papillata. Other characterising species in the northern part concerning absolute abundances were Abraliopsis pfefferi; Pyroteuthis margaritifera and Onychoteuthis banksii. Samples south of the STCZ were characterised by relatively high abundances of Abraliopsis pfefferi, rhynchoteuthion stages of Ommastrephidae, Onychoteuthis banksii and Selenoteuthis scintillans. The cephalopod fauna of the southern Sargasso Sea differed from that of the northern area by relatively higher abundances of Selenoteuthis scintillans and ommastrephid species as well as by low numbers of cranchiid species, especially Leachia lemur.

Taxa which exclusively occurred north of the subtropical convergence, though mostly in low abundances, were Ancistrocheirus lesueuri, Chtenopteryx sicula, Brachioteuthis sp., Chiroteuthis sp., Helicocranchia papillata, Taonius parvo and Argonauta argo.

The calculation of different dominance and diversity indices for the pooled species densities north and south of the front reflected the observed differences between the two areas (Table 3). 18 different species, compared to 10 in the southern part of the Sargasso Sea, were identified in the north (Ommastrephidae were not included at the species level) and the density of early life stages of cephalopods was more than 3 times higher. The Magalef index D and the diversity index H' (Shannon) showed higher values for the northern part of the Sargasso Sea, whereas Pielou's evenness index $(\mathrm{J})$ was slightly smaller. This was due to the dominance of just one species, Leachia lemur, in the northern area and the relatively even distribution of species abundances in the south.

Tab. 2. SIMPER-Analysis: Discriminating species between the northern and the southern part of the Sargasso Sea. Species are ordered in decreasing contribution (\%) to the total dissimilarity up to $90 \%$ cumulative contribution.

\begin{tabular}{|c|c|c|c|c|}
\hline Species & $\begin{array}{c}\text { Southern Sargasso Sea } \\
\text { Average abundance }\end{array}$ & $\begin{array}{l}\text { Northern Sargasso Sea } \\
\text { Average abundance }\end{array}$ & Contribution \% & Cum. Contr. \% \\
\hline Leachia lemur & 0.04 & 1.14 & 17.86 & 17.86 \\
\hline Selenoteuthis scintillans & 0.31 & 0.12 & 8.96 & 26.82 \\
\hline Helicocranchia sp. & 0 & 0.36 & 8.24 & 35.05 \\
\hline Ommastrephidae & 0.22 & 0.09 & 7.9 & 42.95 \\
\hline Onychoteuthis banksii & 0.21 & 0.29 & 7.64 & 50.59 \\
\hline Pyroteuthis margaritifera & 0.05 & 0.32 & 7.17 & 57.76 \\
\hline Megalocranchia sp. & 0.08 & 0.29 & 7.03 & 64.79 \\
\hline Abraliopsis pfefferi & 0.25 & 0.49 & 5.99 & 70.78 \\
\hline Brachioteuthis sp. & 0 & 0.08 & 5.63 & 76.41 \\
\hline Pterygioteuthis giardi & 0.03 & 0.06 & 4.03 & 80.43 \\
\hline Chiroteuthis sp. & 0 & 0.07 & 3.08 & 83.51 \\
\hline Ancistrocheirus lesueuri & 0 & 0.04 & 2.98 & 86.49 \\
\hline Argonauta argo & 0 & 0.06 & 2.94 & 89.43 \\
\hline
\end{tabular}

Tab. 3. Univariate indices of the northern and the southern Sargasso Sea regions. Rhynchoteuthion stages of the family Ommastrephidae were not included on the species level.

\begin{tabular}{lcc}
\hline & Southern Sargasso Sea & Northern Sargasso Sea \\
\hline No. of species & 10 & 18 \\
density [N/1000m $\left.{ }^{3}\right]$ & 14.832 & 53.614 \\
Magalef species richness (D) & 3.337 & 4.269 \\
Pielou`s evenness (J) & 0.832 & 0.781 \\
Shannon (H'(log e)) & 1.917 & 2.257 \\
\hline
\end{tabular}




\section{Discussion}

\section{Sampling methods}

The collection of early life stages of cephalopods with zooplankton nets has advantages and limitations. Advantages are the considerable lower avoidance effects of young and small planktonic cephalopods in comparison to their fast swimming adults (Piatkowski et al. 1993; Piatkowski 1998). The sampling devices used in this study, Bongo net and IKMT6, are supposed to sample small paralarvae, even of the muscular type, effectively (Roper 1977; Rodhouse et al. 1992). Limitations are caused by the seasonal occurrence of early life stages of those species, which do not spawn year round, making them susceptible to plankton sampling only shortly after spawning events. Furthermore, spawning areas are not always identical with the distributional range of the adults. Hence, the distribution patterns of the early life stages do not necessarily reflect those of the adults.

\section{Cephalopod families and major species: Bongo and IKMT6 catches}

In this study the cephalopod fauna was investigated for the first time in an extensive area of the Sargasso Sea. Mesopelagic cephalopods such as the Cranchiidae and Enoploteuthidae dominated the catches, because most of their hatchlings occur in nearsurface waters before they exhibit a marked ontogenetic descent to develop into the juvenile and adult stages (Roper and Young 1975; Young 1978). In general, a typical oceanic cephalopod community was present. The species composition was similar to other collections of pelagic cephalopods in the subtropical western North Atlantic (Voss 1960; Gibbs and Roper 1970; Lu and Roper 1979; Lea 1984; Dawe and Stephen 1988), but was depauperate of shelf associated species such as Myopsida and some Ommastrephidae (e.g. Illex illecebrosus) as well as early life stages of benthic Octopoda. The same families, Cranchiidae and Enoploteuthidae, dominated in our study and in the collections of a one degree square area south east of Bermuda (Gibbs and Roper 1970). The comparison of the species composition of our and the former studies, which mainly collected juvenile to adult specimens, indicated that most of the cephalopod species seem to spawn in early spring or year round, respectively. For most oceanic cephalopods only scattered information about spawning periods exist. Peak spawning time of e.g. Abraliopsis pfefferi, investigated at Deepwater Dumpsite 106 (Lu and Roper 1979) was estimated to take place primarily in summer, though spawning females occurred already in spring. In the present collection early life stages of Abraliopsis pfefferi represented the second most abundant species. Therefore, spawning was likely to have started already in the early months of the year. From records of Megalocranchia megalops collected during their study, Lu and Roper (1979) concluded that this species is spawning from winter to early spring. This agrees to the occurrence of recently hatched specimens in our study.

\section{Distribution of cephalopods in relation to the thermal front}

In the eastern North Atlantic Lu and Clarke (1975) observed an increase of cephalopod abundances and species number from north to south, from temperate to subtropical and tropical regions. This seems to be also true for the western North Atlantic. Dawe and Stephen (1988) accounted the north wall of the Gulf Stream as a boundary which restricts the distribution of tropical-subtropical cephalopod species to higher latitudes. In contrast, our sampling in the relatively small area of the Sargasso Sea revealed reverse relationships: Abundances and species diversity were significantly higher in the northern part of the investigated area. This observation was also demonstrated for small invertebrate zooplankton (Böttger 1982), epipelagic copepods (Colton et al. 1975) and mesopelagic 
fishes (Backus et al. 1969). These studies related the differences to the position of the STCZ, characterised by a distinct thermal front.

In March 1993 the front was located at a latitude of approximately $27^{\circ} 20^{\prime} \mathrm{N}$. This lies in the region of pronounced frontogenesis, which was described in the latitude range of $22^{\circ}$ $32^{\circ} \mathrm{N}$ (Voorhis and Hersey 1964) or in more recent studies at $26-32^{\circ} \mathrm{N}$ (Halliwell et al. 1991a, $\mathrm{b}, 1994)$. The front forms in the upper $200 \mathrm{~m}$, where the colder water of the northern Sargasso Sea converges with the warmer mixed layer of the southern Sargasso Sea (Halliwell et al. 1991a; Wegner 1982). It is usually detectable by a temperature gradient of $1^{\circ} \mathrm{C}$ within a distance of $10 \mathrm{~km}$ (Voorhis and Hersey 1964). The most obvious feature during our cruise was the strong stratification of the water mass south of the STCZ which limited the mixing of the surface layer. In the same season like our investigation Ryther and Menzel (1960) measured near Bermuda high differences in primary production. South of $30^{\circ} \mathrm{N}$ they detected a rapid decline of productivity to approximately ten percent of the stations at the northern end of their transect $\left(35^{\circ} \mathrm{N}\right)$. This strong gradient of primary production coinciding with the position of the front is likely to have an influence on the distribution of zooplankton, as proposed by Backus et al. (1969). Cold core rings, separated from the Gulf Stream and enclosing cold and nutrient rich slope water, possibly enhance this effect (Ortner et al. 1978). Niermann (1986) observed a decreasing abundance of species and individuals of Sargassum natans epibionts in the southern part of the Sargasso Sea. He attributed this decrease to a lower primary production and, thus a lack of suitable food in this region. In the waters north of the thermal front Böttger (1982) measured a 2-3 times higher microzooplankton biomass than in the stratified waters south of it. This small size fraction of zooplankton is an important food resource for fish larvae (Arthur 1977) and likely sustains higher abundances of early life stages of cephalopods, supporting the remarkable increase in the cephalopod densities north of $29^{\circ} \mathrm{N}$. Despite the differences in abundances previous studies also noted north-south differences in the biota of the Sargasso Sea (Backus et al. 1969; Colton et al. 1975; Böttger 1982) with species diversity being higher in the northern area. This was also observed for the early life stages of cephalopods. Seven species/ genera were exclusively found in the north. Furthermore, different species dominated the cephalopod assemblages. In the north the cranchiid Leachia lemur was by far the prevailing species. According to Voss et al. (1992) it is restricted to the North Atlantic Subtropical Region west of about $50^{\circ} \mathrm{W}$ and seems to be endemic for the northern and southern Sargasso Sea. The high abundance and the centre of distribution of Leachia lemur north of the STCZ is probably attributed to the supposed higher productivity in that area. Although the genus Leachia is generally confined to low-productive subtropical waters, increased abundances of cranchiids always appear to be related to areas of intensified productivity (Voss 1988).

In comparison, Selenoteuthis scintillans, besides Leachia lemur mainly responsible for the north-south differences in species composition (SIMPER), was relatively scarce in the northern area. Its geographical distribution in the western North Atlantic extends from approximately $8^{\circ} \mathrm{N}$ to $39-41^{\circ} \mathrm{N}$ (Voss and Stephen 1992), completely covering the investigated part of the Sargasso Sea. The conspicuous low abundances of Selenoteuthis scintillans found north of the STCZ correspond to the densities estimated by Lu and Roper (1979). Their results and our study indicate that the northern Sargasso Sea already represents the northern boundary of distribution for this species. Supported by the observation that the occurrence of Selenoteuthis scintillans north of the Gulf Stream is restricted to warm core eddies (Voss and Stephen 1992), temperature seems to be the limiting factor. 
In conclusion, the distribution patterns of early life stages of cephalopods confirm that the thermal front represents a distinct boundary, both in species composition and in abundance, with a considerable decrease from north to south (Backus et al. 1969; Colton et al. 1975; Böttger 1982; Lea 1984). The latitudinal decrease is not gradual, but pronounced at the front. If this is also true for adult cephalopods is still in question. As juvenile and adult squids are highly mobile and mesopelagic species inhabit completely different parts of the water column compared to their hatchlings, possible north-south differences are more difficult to detect. In order to understand the influence of the hydrography on the distribution patterns of oceanic cephalopods, it is necessary to achieve a better picture of the overall distribution of cephalopods in the western North Atlantic and to improve the knowledge about their biology, i.e. spawning periods, sites and feeding habits.

\section{Acknowledgements}

We wish to thank Prof. D. Schnack, the initiator and chief scientist of RV Poseidon cruise 200/1, for his encouragement and support. Thanks are given to Drs. N. Rohlf and K. Wieland who left the valuable cephalopod collection in our hands and to Prof. N. Voss for fundamental taxonomic advice. This study was supported by grants of the Deutsche Forschungsgemeinschaft DFG (Pi 203/6-1, Pi 203/6-2). 


\section{Literature cited}

Arthur DK (1977) Distribution, size, and abundance of microcopepods in the California Current system and their possible influence on survival of marine teleost larvae. Fish Bull 75: 601-611

Ashjian CJ, Smith SL, Flagg CN, Mariano AJ, Behrens WJ, Lane PVZ (1994) The influence of a Gulf Stream meander on the distribution of zooplankton biomass in the Slope Water, the Gulf Stream, and the Sargasso Sea, described using a shipboard acoustic Doppler current profiler. Deep-Sea Res 41: 23-50

Backus RH, Craddock JE, Haedrich RL, Shores DL (1969) Mesopelagic fishes and thermal fronts in the western North Atlantic. Mar Biol 3: 87-106

Berry SS (1920) Preliminary diagnoses of new cephalopods from the western Atlantic. Proc US Natl Mus 58: 293-300

Böttger RC (1982) Studies on the small invertebrate plankton of the Sargasso Sea. Helgol Meeresunters 35: 369383

Bray JR, Curtis JT (1957) An ordination of the upland forest communities of southern Wisconsin. Ecol Monogr 27: $325-349$

Cairns SD (1976) Biological results of the University of Miami deep-sea expeditions 118 cephalopods collected in the Straits of Florida by the R/V Gerda. Bull Mar Sci 26: 233-272

Clarke KR, Warwick RM (1994) Change in marine communities: An approach to statistical analysis and interpretation. Natural Environment Research Council, UK, 144pp

Clarke KR, Warwick RM (2001) Primer-E (5) Computer Program 2001. Natural Environmental Research Council, UK

Colton JB, Smith DE, Jossi JW (1975) Further observations on a thermal front in the Sargasso Sea. Deep-Sea Res 22: 433-439

Dawe EG, Stephen SJ (1988) The cephalopod assemblage of the Gulf Stream System east of 60 degree W. Malacologia 29: 235-245

Deevey GB (1971) The annual cycle in quantity and composition of the zooplankton of the Sargasso Sea off Bermuda. I. The upper 500m. Limnol Oceanogr 16: 219-240

Deevey GB, Brooks AL (1977) Copepods of the Sargasso Sea off Bermuda: Species composition and vertical and seasonal distribution between the surface and 2000m. Bull Mar Sci 27: 256-291

Field JG, Clarke KR, Warwick RM (1982) A practical strategy for analysing multispecies distribution patterns. Mar Ecol Progr Ser 8: 37-52

Gibbs RH, Roper CFE (1970) Ocean Acre Preliminary report on vertical distribution of fishes and cephalopods. In: Farquhar GB (ed) Proceedings of an International Symposium on Biological Sound Scattering in the Ocean Washington DC. Department of Navy, Maury Center Report 005, pp 119-133

Goericke R, Welschmeyer NA (1998) Response of Sargasso Sea phytoplankton biomass, growth rates and primary production to seasonally varying physical forcing. J Plankton Res 20: 2233-2249

Goldman DA (1993) Distribution of cephalopod paralarvae across the Florida Current front in the Florida Keys: Preliminary results. Rev Biol Trop 41: 31-34

Halliwell GJ, Ro YJ, Cornillon P (1991a) Westward-propagating SST anomalies and baroclinic eddies in the Sargasso Sea. J Phys Oceanogr 21: 1664-1680

Halliwell GJ, Cornillon P, Brink KH, Pollard RT, Evans DL, Regier LA, Toole JM, Schmitt RW (1991b) Descriptive oceanography during the Frontal Air-Sea Interaction Experiment: Medium- to large-scale variability. J Geophys Res 96: 8553-8567

Halliwell GJ, Peng G, Olson DB (1994) Stability of the Sargasso Sea subtropical frontal zone. J Phys Oceanogr 24: $1166-1183$

Jackson GA (1980) Phytoplankton growth and zooplankton grazing in oligotrophic oceans. Nature 284: 441

Lea CE (1984) Pelagic cephalopods of the Florida Current. Dissertation, Texas A\&M University, 235p 
Lu CC, Clarke MR (1975) Vertical distribution of cephalopods at $40^{\circ} \mathrm{N}, 53^{\circ} \mathrm{N}$ and $60^{\circ} \mathrm{N}$ at $20^{\circ} \mathrm{W}$ in the North Atlantic. J Mar Biol Assoc UK 55: 143-163

Lu CC, Roper CFE (1979) Cephalopods from the Deepwater Dumpsite 106 (western Atlantic): vertical distribution and seasonal abundance. Smithson Contrib Zool 288: 1-36

Niermann U (1986) Distribution of Sargassum natans and some of its epibionts in the Sargasso Sea. Helgol Meeresunters 40: 343-353

Ortner PB, Wiebe PH, Haury L, Boyd S (1978) Variability in zooplankton biomass distribution in the Northern Sargasso Sea: the contribution of Gulf Stream cold core rings. Fish Bull 76: 323-334

Peile AJ (1926) The Mollusca of Bermuda. Proc Malacol Soc London 17: 71-98

Pfeffer G (1912) Die Cephalopoden der Planktonexpedition: Zugleich eine monographische Übersicht der Oegopsiden Cephalopoden. In: Hensen VAC (ed) Ergebnisse der Plankton Expedition der Humboldtstiftung 2F(a). Lipsius \& Tischler, Kiel, pp 1-815

Piatkowski U, Welsch W, Röpke A (1993) Distribution patterns of the early life stages of pelagic cephalopods in three geographically different regions of the Arabian Sea. In: Okutani T, O’Dor RK, Kubodera T (ed) Recent advances in cephalopod fisheries biology. Tokai University Press, Tokyo, pp 417-431

Piatkowski U (1998) Modern target sampling techniques provide new insights into the biology of early life stages of pelagic cephalopods. Biol Mar Medit 5: 260-272

Rodhouse PG, Symon C, Hatfield EMC (1992) Early life cycle of cephalopods in relation to the major oceanographic features of the Southwest Atlantic Ocean. Mar Ecol Prog Ser 89: 183-195

Roper CFE, Young RE (1975) Vertical distribution of pelagic cephalopods. Smithson Contrib Zool 209: 1-48

Roper CFE (1977) Comparative captures of pelagic cephalopods by midwater trawls. Symp Zool Soc Lond 38: 61-87

Ryther JH (1963) Geographical variations in productivity. In: Hill MN (ed) The Sea. Wiley, New York, pp 347-380

Ryther JH, Menzel DW (1960) The seasonal and geographic range of primary production in the western Sargasso Sea. Deep-Sea Res 6: 235-238

Schnack D, Piatkowski U, Wieland K (1994) Fahrtbericht zur Aal-Expedition mit FS Poseidon (Reise 200/1) in die Sargasso See im Frühjahr 1993. Ber Inst Meereskd Christian-Albrechts-Univ Kiel 248: 1-33

Voorhis AD, Hersey JB (1964) Oceanic thermal fronts in the Sargasso Sea. J Geophys Res 69: 3809-3814

Voorhis AD (1969) The horizontal extent and persistence of thermal fronts in the Sargasso Sea. Deep-Sea Res 16: $331-337$

Voss GL (1960) Bermudan cephalopods. Fieldiana Zoology 39: 419-446

Voss GL, Stephen SJ (1992) Family Lycoteuthidae, Pfeffer, 1908. In: Sweeney MJ, Roper CFE, Mangold KM, Clarke MR, von Boletzky S (ed) Larval and juvenile cephalopods: A manual for their identification. Smithson Contrib Zool 513, pp 67-71

Voss NA, Stephen SJ, Dong Zh (1992) Family Cranchiidae, Prosch, 1849. In: Sweeney MJ, Roper CFE, Mangold KM, Clarke MR, von Boletzky S (ed) Larval and juvenile cephalopods: A manual for their identification. Smithson Contrib Zool 513, pp 187-210

Voss NA (1988) Evolution of the cephalopod family Cranchiidae (Oegopsida). In: Clarke MR, Trueman ER (ed) The Mollusca 12: Paleontology and Neontology of Cephalopods. Academic Press Inc, London, pp 293-314

Wegner G (1982) Main hydrographic features of the Sargasso Sea in Spring 1979. Helgol Meeresunters 35: 385400

Wiebe PH, Flier GR, Davis CS, Barber V, Boyd SH (1985) Macrozooplankton biomass in Gulf Stream warm-core rings: spatial distribution and temporal changes. J Geophys Res 90: 8885-8901

Young RE (1978) Vertical distribution and photosensitive vesicles of pelagic cephalopods from Hawaiian waters. Fish Bull 76: 583-615 